\title{
APPLICATION OF AN APPROACH TO THE INNOVATION MANAGEMENT IN MICRO AND SMALL ENTERPRISES
}

\section{Moises Andrade Coelho State Secretary of Science, Technology and Innovation of Amazonas, Brazil \\ E-mail: moises.acoelho@gmail.com}

Submission: 19/11/2013

Revision: 04/12/2013

Accept: 23/12/2013

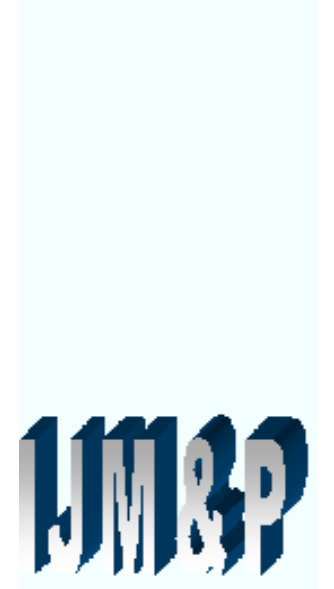

\section{ABSTRACT}

This research aims to present the application of a management approach focused innovation for micro and small enterprises (MSEs). In the approach the study of the problem is characterized as a qualitative research and in relation to its goals can be characterized as an action research. The delimitation of the universe was made by a small enterprise in the food industry and the research techniques used were indirect documentation (desk research and literature), the intensive direct observation (observation and interview) and extensive direct observation (forms). The results demonstrate the usefulness of the approach to innovation management aimed at increasing competitiveness and improving working conditions in MSEs. The relevance of this study lies in applying an approach that enables an understanding of the internal and external environment of the enterprise (ambidexterity) and considers the process of innovation as a social nonlinear construct.

Keywords: Innovation management; Innovation; Small enterprise; Amazonas. 


\section{INTRODUCTION}

Currently, knowledge and technological advances in the development of new offers, products and services, and how they create and launch these offerings are an important competitive advantage. Innovation is something new that adds value or social wealth, going far beyond a new product, which may be related to new technologies, new processes, new marketing practices, small change, etc. Innovation is not limited to manufactured goods, can be found in the service sector with enhancements that involve promptness, quality and effectiveness of their care services (TIDD, et al., 2008).

According to Schumpeter (1961) innovation is the impetus that keeps running the machine of capitalism through a process called "creative destruction." The "creative destruction" allows opening to new opportunities and changes in existing players (BESSANT, et al., 2005).

The mortality rate of micro and small enterprises (MSEs) in Brazil was considered quite high (over 50\%), however, in 2006 the average mortality rate was around $26.9 \%$. In the case of the Amazon, in 2006, the rate was the second highest in the country with $41.2 \%$ of MSEs that closed its activities before completing two years of life. Only the state of Pernambuco with $41.8 \%$ had a higher rate during this period (SEBRAE, 2011).

In 2010 of U.S. $\$ 201.9$ billion in export business only U.S\$ $2.0(0.9 \%)$ billion of exports were made by MSEs. The Amazonas exported U.S\$1,119.3 million (0.5\% of total exports from Brazil) by 202 firms, 71 of the total (35\%) were micro and small enterprises that exported U.S\$ 9.8 million, approximately $0,9 \%$ of the total in state (ALTOÉ, et al., 2011).

The above data added to recent results of the 4th edition of the Survey of Technological Innovation - PINTEC corroborate the situation in which small businesses do not have or have few problems with innovative activities and the qualification of the workforce (IBGE, 2010).

Therefore, in the case of the Amazonas and Brazil a framework where the MSEs represent the vast majority of companies, however as we have features companies with high mortality (especially the Amazon), not exporting, problems with qualification of manpower and not innovative. One way to survive, grow and develop 
sustainably in globalized and competitive advantages which are strongly related to innovation is through a methodology that implements the innovation management in these organizations.

Thus, the relevance of this research consists in the presentation and adoption of an approach to innovation management to be applied by the enterprise or by collaboration with a university in order to make it more competitive through innovations that meet their needs. The research is structured into four parts: the first is a brief review of the literature of the subject innovation management, followed in a second stage by presenting the innovation management approach that will be adopted in the study and in the third part describes the methodology adopted in research. Finally, the fourth section presents the results of applying the approach to innovation management in a small enterprise in the food sector, the final considerations and references used.

\section{INNOVATION MANAGEMENT}

The process of innovation can assume in companies different forms, well as, its realization may be made of different means in diverse sectors of economy, however, observes the possibility of adoption of models innovation management with the objective of systematizing this development process of innovations in companies.

From the point of view of Drucker (1986), entrepreneurs need to learn to practice systematic innovation, in this way, successful entrepreneurs try to create new values and different and new and different sensations instead of seeking for innovations sensational. They convert one "stuff" in a "resource" or combine existing resources in a new and more productive configuration. For the author, systematic innovation consists in searching, frequent and organized, of change and systematic analysis of the opportunities that these changes might offer for economic or social innovation.

Regarding innovation management Tidd, et al. (2008) mention that there is consensus on two factors: (1) Innovation is not an isolated event, it is a process and as such needs to be managed, and (2) innovation can be managed by manipulation of the influences on the process affecting the results.

Innovation management helps the enterprise to innovate and position itself against the competition, helps to work with quality management standards and meet

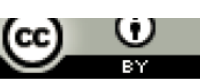


the requirements of the environment (COTEC, 1999). The effectiveness of innovation management is more related to the ability to manage an internal system of innovation with a number of dimensions that do one thing particularly well, such as investment in research and development (R\& D) and risk management, for example (BESSANT, et al, 2005).

Studies of innovation management can be grouped into two categories in order to analyze different aspects of innovative processes as Nieto (2003):

1. Studies at the macro level: taking society, the economic system and the industry as units of analysis and much of the research carried out by the industrial economy, sociology and history;

2. Studies at the micro level: The units of analysis a business, department, project or product.

Subsequently, Longanezi, et al. (2008) presented two types of models of innovation management: (1) the descriptive models, and (2) the normative models. The descriptive models work with innovation at the macro and meso (analysis unit of society, the economic system or industry) seeking a theory that explains the innovative process from central questions such as "who, when, where, why and when ". Divided into static and dynamic, with the main focus of the static classification of different types of innovation and the dynamic evolution of the process in time. In this type of models can cite Abernathy and Utterback (1978), Dosi (1982), Foster (1986), Christensen (1997), Chesbrough (2003) and Berkhout, et al. (2010).

The normative models analyze innovation at the micro level (own enterprise), stem, usually of practical experiences and case studies and seek to analyze the modus operandi in the innovation process in companies. Can be easily made into procedures and practices to be adopted in the corporate and operational levels useful in implementing the strategies presented. Examples of this model has Kline and Rosenberg (1986), Rothwell (1994), Kelley and Littman (2001) Bessant et al. (2005), Sawhney, et al. (2006), Hansen and Birkinshaw (2007), Tidd, et al. (2008), Silverstein, et al. (2009). 
DOI: 10.14807/ijmp.v5i3.168

\section{APPROACH TO INNOVATION MANAGEMENT IN MICRO AND SMALL ENTERPRISES}

This topic presents recommendations for the implementation of an approach to innovation management for micro and small enterprises. The goal is to provide general recommendations in order to demonstrate the difficulties and facilitate the achievement of success in this process of innovation management. For further details of the proposed approach in this study is recommended reading Coelho (2012).

These recommendations can be used for the management of innovation in the enterprise and also for the solution of a specific problem in a sector. The following table (table 1) shows the steps containing the methods and tools that can be used for application in the enterprise. These steps are not linear but rather allow for a constant overlap between them, as in step turns out being necessary to implement new survey information in order to perform the projecting transformations.

Table 1: Methods and tools adopted in the case

\begin{tabular}{cc} 
STEPS & METHODS AND TOOLS \\
\cline { 2 - 2 } & Individual interview \\
\cline { 2 - 2 } athering information & Collective interview \\
\cline { 2 - 2 } & Direct observation \\
\cline { 2 - 2 } & Process/Activity analysis \\
\cline { 2 - 2 } & Innovation Audit \\
\cline { 2 - 2 } & Audit capacity \\
\cline { 2 - 2 } & Customer Satisfaction \\
\hline Diagnosis of current situation & Industry Analysis \\
\cline { 2 - 2 } & SWOT of current situation \\
\hline Selection and Prioritization & Meeting \\
\hline Resources & Selection of opportunities \\
\hline Implementation & Resource definition \\
\hline Learning & Innovation planning \\
\hline Evaluation & Learn check list \\
\hline
\end{tabular}

We have a roadmap with general recommendations that are necessary apply the management approach of innovation and summarized in Table 2: 
1. The approach starts with the realization of an interview with the owner (s) and/or managers of the main areas of the enterprise with the goal of raising the initial information;

2. Ensure press conferences with employees and do individual interviews with suppliers to identify possible areas for improvement the interviews with employees should avoid the presence of managers not to spoil the spontaneity of responses;

3. Plan direct observations of the work situations of productive area / operations or areas involved in innovation management (sales, HR, distribution). These observations should be considered as observable the gestures, postures, actions and communications between employees and recorded;

4. Perform a SWOT analysis of the enterprise with both the owner and / or managers as involved with the enterprise's employees;

5. Apply the form of customer satisfaction: the forms need to be designed so that the enterprise can identify the level of customer satisfaction, improvements and probable latent needs;

6. Check market trends (technology, management, marketing, etc.) related to the area of activity of the enterprise: the "S" system (SEBRAE, SESI, SENAI, SENAT, SENAR and SENAC) offers important studies and know-how related to probable market trends. The internet and benchmarking with other major competitors are fundamental tools for monitoring and surveillance technology;

7. Apply auditing tools and innovation capacity: the forms need to be applied directly to the owner or the responsible sectors (managers, supervisors, etc.). After applying these tools should mount the radar and innovation capacity of the current stage of the enterprise;

8. Produce a map of the current situation: the map allows you to view, in general, the result of the application of various tools providing the current status of the enterprise and allowing the preparation of possible actions (innovations) organizational;

9. Conduct meeting with all stakeholders to raise awareness and discuss the opportunities for improvement: the seminar to be held in the enterprise with 
the participation of the majority of employees and the stakeholders (owners, managers, etc.) with the aim of selecting priority actions. This number can range between ten and fifteen shares;

10. After the selection of the priority actions is the prioritization of opportunities for innovation: the enterprise needs to clearly define what will be the criteria used to select the various actions outlined in the map of the current situation. The ideal will be a number between five and seven actions;

11. Define the resources that will be allocated to apply actions through the sheet resource definition: In this stage the owner's equity is fundamental for approval or otherwise of the actions selected;

12. Undertake planning for innovation in order to facilitate the implementation and monitoring of actions: planning for innovation is formalizing the process of innovation management in the enterprise, measures of success may become important of indicators organizational, strategic or processes;

13. Form a team to conduct the process of innovation management: the case of micro-enterprises all employees are responsible for the implementation and accountability of actions;

14. Implement actions in accordance with the schedule established in planning for innovation: the service schedule prepared in form to organize the process of organizational change and reduce distrust by employees;

15. In some cases this will require changes to project through tools such as prototypes, scale models, industrial designs, etc.;

16. Apply the checklist learning at all stages of the model: the checklist is an important tool because it allows to identify trouble spots and provides greater organizational learning;

17. Periodically evaluate the implemented actions: the enterprise needs to evaluate periodically the actions in order to reduce losses and realign with the objectives outlined above. In the case of periodic evaluations, the enterprise sets a period for them to occur ranging from six months (minimum) and one year (maximum); 
INDEPENDENT JOURNAL OF MANAGEMENT \& PRODUCTION (IJM\&P)

http://www.ijmp.jor.br

v. 5, n. 3, June - September 2014

ISSN: 2236-269X

DOI: 10.14807/ijmp.v5i3.168

18. In periodic evaluations it is necessary application forms audit of innovation and ability again to identify the improvements or not.

19. Adjusting actions in accordance with the needs identified in periodic evaluations (based on audit capacity and innovation); a continuous improvement process must be developed by all employees of the enterprise;

20. Restart the step of gathering information: after the final assessments restarts the stage of initial surveys with the aim of making innovation a cyclical process within the enterprise. The actions that were not contemplated to be included in the next period.

Table 2: Steps and topics adopted in the case

\begin{tabular}{c|c}
\hline STEPS & TOPIC \\
\hline Gathering information & Topic 1 to 7 \\
\hline Diagnosis of current situation & Topic 8 \\
\hline Selection/ Prioritization & Topic 9 to 10 \\
\hline Resources & Topic 11 \\
\hline Implementation & Topic 12 to 15 \\
\hline Learning & Topic 16 \\
\hline Evaluation & Topic 17 to 20 \\
\hline
\end{tabular}

Finally, all the results of the improvements and innovations need to be communicated to employees to feel more valued, recognized and understand its importance to the process of innovation in the organization.

\section{METHODOLOGY}

The present study, in addressing its problem, characterized as a qualitative research (SILVA; MENEZES, 2005), conducted in a enterprise in the food sector in the city of Manaus. In relation to their goals, this work is characterized as an action research (GIL, 2002; TRIPP, 2005; THIOLLENT, 2007; MCNIFF, 2002), as was concerned with the resolution of organizational problems through the application of management tools innovation in a small enterprise in the state of Amazonas in practice.

In this study the model used for the management of innovation approach was followed in Coelho (2012). The proposed approach consists of seven steps (gathering information, diagnosis of the current situation, selection/prioritization, resources, implementation, learning and evaluation) were used throughout the action 
INDEPENDENT JOURNAL OF MANAGEMENT \& PRODUCTION (IJM\&P)

http://www.ijmp.jor.br

v. 5, n. 3, June - September 2014

ISSN: 2236-269X

DOI: 10.14807/ijmp.v5i3.168

research. This approach allows considering the comings and goings of the innovation process for stages allowing the identification and solution of real internal needs and external (opportunities) of companies. Thus, the approach considers the innovation process as a nonlinear activity and above all a social construction.

The delimitation of the universe was made in a small enterprise located in the city of Manaus/AM in the food industry, more specifically, bakery. Access enterprise via professional contact occurred; the initial steps (gathering information, diagnosis of the current situation, selection/prioritization and resources) generally demanded 45 days and step to the implementation of actions lasted five months. The sample studied was a non-probabilistic intentional (MARCONI, 1990). The research techniques used to operationalize the study were: (1) the indirect documentation (desk research and literature), (2) the intensive direct observation (observation and interview), and (3) the extensive direct observation (forms).

This research used open structured interviews, individual (owners) and collective (employees) from a script where identified key information and complementary forms were applied in the studied enterprise (VERGARA, 2009). In the case of press conferences, they followed the approach proposed by Thiollent (2007) as a source of data collection of action research. The structured observation (VERGARA, 2009) was another technique used to identify characteristics of employees and owners with the aim of a better understanding of reality.

The overall observation came from the methodology Guérin et al. (2001) in which from the collective and individual interviews (demand) the observer conducted a brief analysis of tasks with special focus on area bakery. Were considered as observed gestures, postures, actions and communications among bakers and helpers, and communications with other areas (confectionery shop and administration).

The forms (adapted) were used: (1) audit capacity (FNQ, 2009a; 2009b), (2) innovation audit (DE JONG; MARSILI, 2006; FREEL, 2003; 2005; DE JONG; VERMEULEN, 2006); (3) benchmarking (BÜYÜKÖZKAN; MAIRE, 1998), (4) Selection of opportunities (CARVALHO, 2009), (5) Definition of resources (CARVALHO, 2009), and (6) planning for innovation (HARVARD BUSINESS 
ESSENTIALS, 2011) for application of techniques/innovation management tools from the enterprise.

The tools and techniques used in this research and applied in Alpha Enterprise are presented in table 3 . Aiming to maintain the confidentiality of the enterprise will be called Alpha enterprise, this secrecy was requested by the owners. In all individual interviews were conducted with two individuals, one owner and the other a people manager of the enterprise. The duration of the interview was between 45 minutes and 60 minutes. Regarding collective interviews with employees, they occurred with 16 employees (a total of 21 employees). The average length of the interviews was 30 minutes in each sector due to occur during daily activities.

Table 3: Distribution of interviews.

\begin{tabular}{l|c}
\hline \multicolumn{2}{c}{ Distribution of interviews } \\
\hline \multicolumn{1}{c}{ Sector } & Alpha enterprise \\
\hline Top Management & 1 partner \\
Confectionery & 7 employees \\
Bakery & 4 employees \\
Shop & 5 employees \\
\hline
\end{tabular}

\section{DATA ANALYSIS}

The enterprise studied is a small enterprise with 21 employees located in Manaus, is in the business of baking for ten years and has as main products manufactured in addition to breads, pies, cakes, savory snacks and breakfast. Access to the enterprise occurred through previous contact with the owner via professional statement.

The quality of products, service and price are the main differences mentioned by the enterprise and requested by customers. Sales hit their highest levels in the months of October, November and January, over the months of June and July is considered the weakest.

\subsection{Gathering of information}

The step gathering of innovation information comes from the exploitation of internal and external environment of the enterprise to identify signs or opportunities where the enterprise needs to respond. In this study we used different tools to survey the current situation of the enterprise. 
The study began with visits where interviews were conducted with the owner aiming a better understanding of the enterprise after the interviews were press conferences, the systematic of these interviews took place in the enterprise by sector (bakery and confectionery shop) and started with the clarification the object of study, then were the questions of possible suggestions for improvement or something new for the enterprise. In these interviews followed a small script and ran only the transcription of answers. The interviews took place without the presence of the owners appeared to cause the spontaneous responses of employees.

Direct observation (not participant), following the methodology of Guérin et al. (2001), was performed to enrich the flowchart and understanding of the reality of the enterprise as a whole held seven direct observations, two observations in the confectionery, bakery and three observations on two observations in the store. Each observation lasted for about two hours in the following areas of enterprise Alpha and sought to understand the gestures, postures, actions and communications between employees of the area and with other areas.

In order to identify possible trends in the sector of bakery and confectionery were necessary a visit to SEBRAE Amazonas, the use of a study of industry trends bakery and confectionery (SEBRAE; ABIP, 2009) and access to the site PROPAN (Program support the Bakery), all possible examine important trends in the field of baking, such as automation, food service, packaging, shops, among others.

Applied SWOT analysis (Figure 1) to view the enterprise's positioning in the market environment in which it operates. SWOT analysis considered the positions of both the employees and owner as the observations occurred in the enterprise. Then , we applied two forms: the first, called audit capacity (Figure 1) assesses several dimensions of enterprise management (strategic management, people management, production management, marketing management, information management and socio - environmental), the second form is called audit of innovation (Figure 2) and aims to assess the enterprise's relationship with the various types of innovation (product, process, marketing and organizational) as well as with the various elements that make up the innovation (inputs of innovation, sources of innovation, managerial attitudes, planning for innovation and external orientation). 
DOI: 10.14807/ijmp.v5i3.168

\begin{tabular}{|c|c|c|}
\hline \multirow[b]{2}{*}{ 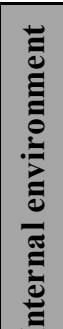 } & Strenghts & Weaknesses \\
\hline & $\begin{array}{l}\text { 1. Price; } \\
\text { 2. Customer; } \\
\text { 3. Location; } \\
\text { 4. Product quality. }\end{array}$ & $\begin{array}{l}\text { 1. Improve cost control and } \\
\text { financial information; } \\
\text { 2. Infrastructure of production; } \\
\text { 3. Little variety of products; } \\
\text { 4. Standardization of the store; } \\
\text { 5. Service employees. }\end{array}$ \\
\hline \multirow{2}{*}{ 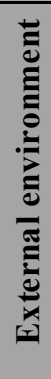 } & $\begin{array}{l}\text { 1. pizzeria; } \\
\text { 2. Service self-service; } \\
\text { 3. Product diversification; } \\
\text { 4. House of Pasta; } \\
\text { 5. Light line. }\end{array}$ & $\begin{array}{l}\text { 1. Competition with informal } \\
\text { bakeries; } \\
\text { 2. New bakeries in the region; } \\
\text { 3. Price of wheat. }\end{array}$ \\
\hline & Opportunities & Threats \\
\hline
\end{tabular}

Figure 1: SWOT Analysis - Alpha Enterprise. Source: Author

At this stage, it was benchmarked with five bakeries considered excellent in Manaus with the aim of increasing knowledge of the practices adopted by them, for this, we adopted the methodology for conducting benchmarking proposed by Büyüközan and Maire (1998). The criteria adopted for this benchmarking study were used: (1) production, (2) product quality, (3) employees, (4) customer profile, (5) services offered; (6) store layout and production and (7) marketing. Interviews were conducted with employees (both in the production area as the commercial area) where they observed the practices adopted by these companies related to the criteria mentioned.

All information gathered in the interviews with the owner and the staff added to the results of the two forms (audit capacity and innovation audit), SWOT analysis, benchmarking and the direct observations allowed to identify the demands which the enterprise needed to improve. To accomplish the step of gathering of information were required 12 visit to the enterprise Alpha in a period of 30 days, counting the period of the data analysis.

\subsection{Diagnosis of current situation}

Respect of the information presented in the stage of data collection and the definition of the lines of action favorable to the enterprise. To facilitate the visualization was created a map of the enterprise's current situation (table 4) where it entered the results of the tools presented and possible solutions and/or actions to be 
developed. This map was presented to the owner and staff of the enterprise in the form of a meeting.

Table 4: Map of the current situation - Alpha enterprise

\begin{tabular}{|c|c|c|}
\hline \multicolumn{3}{|c|}{ MAP OF THE CURRENT SITUATION } \\
\hline TOOLS & CURRENT SITUATION & $\begin{array}{c}\text { POSSIBLE STRATEGIES, } \\
\text { ACTIVITIES, ACTIONS AND } \\
\text { INNOVATIONS }\end{array}$ \\
\hline SWOT Analysis & Figure 1 & $\begin{array}{l}\text { Improve financial control; } \\
\text { Self-service; } \\
\text { Standardization of production; } \\
\text { Stock management; } \\
\text { Expand product mix. }\end{array}$ \\
\hline Benchmarking & $\begin{array}{l}\text { 1. Wide variety of breads, cakes } \\
\text { and pastries; } \\
\text { 2. Standardization of stores; } \\
\text { 3. Climate; } \\
\text { 4. Standardization in the } \\
\text { production area; } \\
\text { 5. Layout service companies; } \\
\text { 6. Production plan. }\end{array}$ & $\begin{array}{l}\text { Change layout of production; } \\
\text { Production plan; } \\
\text { Redesigning care process; } \\
\text { Climate. }\end{array}$ \\
\hline $\begin{array}{l}\text { Audit capacity } \\
\text { (business excellence } \\
\text { model) }\end{array}$ & $\begin{array}{l}\text { Aspects to be improved: } \\
\text { 1. Strategic plan (goals and } \\
\text { indicators); } \\
\text { 2. Financial control; } \\
\text { 3. Performance evaluation; } \\
\text { 4. Job descriptions; } \\
\text { 5. Organizational training; } \\
\text { 6. Production control; } \\
\text { 7. Process mapping; } \\
\text { 8. Quality tools; } \\
\text { 9. Control of suppliers; } \\
\text { 10. Effective marketing actions; } \\
\text { 11. Communication with clients; } \\
\text { 12. Organizational indicators. }\end{array}$ & $\begin{array}{l}\text { Strategic plan; } \\
\text { Financial control; } \\
\text { People management; } \\
\text { Changing the production layout; } \\
\text { Control of suppliers; } \\
\text { Marketing plan; } \\
\text { Customer satisfaction; } \\
\text { Informatization. }\end{array}$ \\
\hline Innovation Audit & $\begin{array}{l}\text { Aspects to be improved: } \\
\text { 1. There were innovations in } \\
\text { processes, marketing and } \\
\text { organizational; } \\
\text { 2. There were innovations in } \\
\text { products, but at random; } \\
\text { 3. Budget and longer for } \\
\text { innovation; } \\
\text { 4. Planning for innovation; } \\
\text { 5. Cooperation with other } \\
\text { companies. } \\
\text { Positive aspects: } \\
\text { 1. Has positive managerial } \\
\text { attitudes; } \\
\text { 2. Inova products, but needs more } \\
\text { systematic. }\end{array}$ & $\begin{array}{l}\text { Form for suggesting improvements of } \\
\text { employees; } \\
\text { Process NPD (New Product } \\
\text { Development) formal; } \\
\text { Develop partnerships with other actors } \\
\text { for innovation. }\end{array}$ \\
\hline
\end{tabular}

\subsection{Selection and prioritization}

The systematic of the meeting held as follows: first, happened the map display of the current status to stakeholders and then came the discussion about what 
actions would be acted upon and what would be delayed based on the map of the current situation. Were chosen ten actions of twenty initially proposed contained in the map of the current situation to compose a spreadsheet selection of opportunities.

Used as criteria for selection of opportunities for innovation: (1) the ratio profit/investment, (2) reducing costs, (3) improving the work environment, and (4) ease of implementation. These criteria were given a score according to the impact of innovation in relation to them. For this selection process used a spreadsheet selection opportunities, this spreadsheet allowed for an easy way to prioritize actions by the appropriateness of the action with the criteria mentioned above.

A total of ten actions selected on the map of the current situation by the owner and employees, five were selected by the spreadsheet (actions with high scores). Finally, the actions chosen were:

1. Standardization of production;

2. Production plan;

3. Changing the production layout;

4. Stock management;

5. New product development.

\subsection{Resources}

This stage is characterized by the definition of the resources necessary for the correct functioning of the innovation process both in relation to knowledge about the technology or equipment. At this time it was used a spreadsheet resource definition that allowed allocate resources in each of the five major actions relating to key aspects of the enterprise (human resources, infrastructure, technology and financial resources). It was attempted to describe the resources needed to achieve the goal of each action and what forms of access to these resources.

\subsection{Implementation}

This step used to Planning for innovation in order to put into practice the actions selected and defined in the previous steps. Planning for innovation has allowed defining what kind of innovation that the enterprise was effectively adopting and what goals it aims to achieve this innovation. Outlined the short-term actions, 
INDEPENDENT JOURNAL OF MANAGEMENT \& PRODUCTION (IJM\&P)

http://www.ijmp.jor.br

v. 5, n. 3, June - September 2014

ISSN: 2236-269X

DOI: 10.14807/ijmp.v5i3.168

measures that served as parameters for these actions and the actions in the long term the enterprise has adopted.

Were prepared three plans for innovation from the five main ideas enabling the enterprise to define what resources would be needed to meet the various actions distinguishing the main sources of support of the main sources of resistance. For this, it was developed a schedule of training for both the owners and the employees for changes in training and professional qualification. The period of implementation of actions lasted five months. The implementations of the actions occurred as follows.

Standardization of production: development and implementation of technical product row of the enterprise (bakery and confectionery shop) where they have been developed in order to standardize the production of confectionery, bakery and shop (snacks). Fact sheets are composed of several components necessary for the production of food, such as ingredients, gross amount/liquidation, unit cost/total method of preparation, assembly and decoration.

Production plan: occurred the preparation, adoption and adaptation of the production plan with the owner, the production plan aimed at improving the control of which would be produced by the bakery in the areas of bakery and confectionery. The production plan contains the product to be produced, the sequence of production, the quantity to be produced and the raw materials needed for production.

Changing the production layout: to change the layout of confectionery production was necessary to expand an area previously used as a stock which provided increased area for preparing food for the food service, in baking, for changing the production layout was necessary to replace the wood oven for a gas furnace. In the case of gas oven choice, rather than the electric furnace, was due to the instability of the power supply in the city of Manaus, after replacement, bakery machines were organized with the aim of following the flow of production.

Changing the layout of the store was the expansion of the store, purchase of equipment for the food service deployment and cooling of the internal space of the store. Were still required to hire two employees (dolly and attendant) to accompany this new service. Finally, there was the implementation of the $5 \mathrm{~S}$ program where a partnership with SENAC allowed employee training and periodic monitoring by Safe Food Program (SBP). 
Stock management: for the improvement of stock management has created a spreadsheet to track of weekly spending based enterprise in the production plan. The stock was closed and only by the signature of an internal drive employees could take the necessary raw materials. The own production planning and data sheets are intended to target a greater control of production. The enterprise Alpha had 15 loaves in its product row at the beginning of the intervention, rising to 21 by the end of the intervention. This diversification was mainly due to change of mind of the owner and due to the training of employees.

New product development: the Alpha enterprise aiming to expand its product line developed a line of breads based on cassava starch and Brazil-nut (Bertholletia excelsa). The cassava starch was used in the proportion of $10 \%$ relative to the amount of flour and this allowed a reduction of production costs allowing the inclusion of Brazil nuts without raising the price of the product. The Brazil-nut was also used in confectionery for the formulation of regional pies and cakes. Added to the Brazil-nut, the enterprise started using the cupuaçu, cupulate (cupuaçu benefited in the form of chocolate) and puxuri (Licaria puchury-major) as the basis for their pies and cakes. The puxuri, also known as angel smell, is used as a cosmetic or food flavoring and was initially used as a medicinal properties in the treatment of insomnia and cramps.

\subsection{Learning}

The learning stage is a time for feedback and aims to learn from both the successes and with errors. In the stage of gathering information applications of tools and techniques enabled the enterprise Alpha a more complete view of the organization, this stems from the fact that this step has enabled the analysis of various viewpoints. Employee participation was crucial to the enrichment of the management model as it enabled a better understanding of what your reality found in the search for solutions to their demands.

Main lessons, the model innovations that rise at all stages of the process, the steps of collecting the information, diagnosis of the current situation, selection/prioritization and resources are fundamental for a correct proposition of actions aimed at the fulfillment of organizational goals. The implementation stage is 
the longest stage to be related to the practice and involve the participation of employees and owner. The model allowed the exchange and the purchase of internal and external knowledge.

\subsection{Evaluation}

Regarding the step evaluation, the results indicate that the Alpha company of the five proposed actions initially (standardization production, stock management, production plan, new product development and modification of production layout) occurred implementing all.

> Standardizing production occurred by the development of chip production techniques;

> Stock management happened by using a spreadsheet to control of raw materials, the product data sheets, the production plan and internal control to employees;

> The production plan was drawn up and implemented appropriate;

$>$ Change the layout and production of store to adapt to the new service food service;

New product development adopted the methodology proposed by Bizguides (SBDC, 2011) to the process of product development resulting in the increase in the number of new products launched, from 15 to 21 loaves in five months. The new products developed using Amazonian inputs (cassava starch, Brazilnut, cupuaçu, cupulate and puxuri) expanded the product portfolio, and develop a completely regional product line focusing on clientele of tourists visiting the city.

Additionally, there was (1) an increase in the number of training staff and owner resulting from new partnerships with SEBRAE, Senac and union of bakeries, (2) implementation of food service for lunch, (3) hiring two employees (one dolly), (4) climate Store, and (5) changes in the layout of the store under the new service. The analysis of radar audit capacity (Figure 2) demonstrates the considerable improvements in the management aspects of production (before 1.31 and after 1.58), especially primary and secondary processes (before 1.00 and after 2.64) resulting from productive innovations and business management (before 1.52 and then 2.50), 
especially strategic management (before 1.18 and then 3.27) resulting from the use of planning for innovation. The people management dimension also showed an increase (before 1.25 and after 1.89) arising from partnerships for capacity building and training. The dimensions of marketing management and information management showed no significant increases.

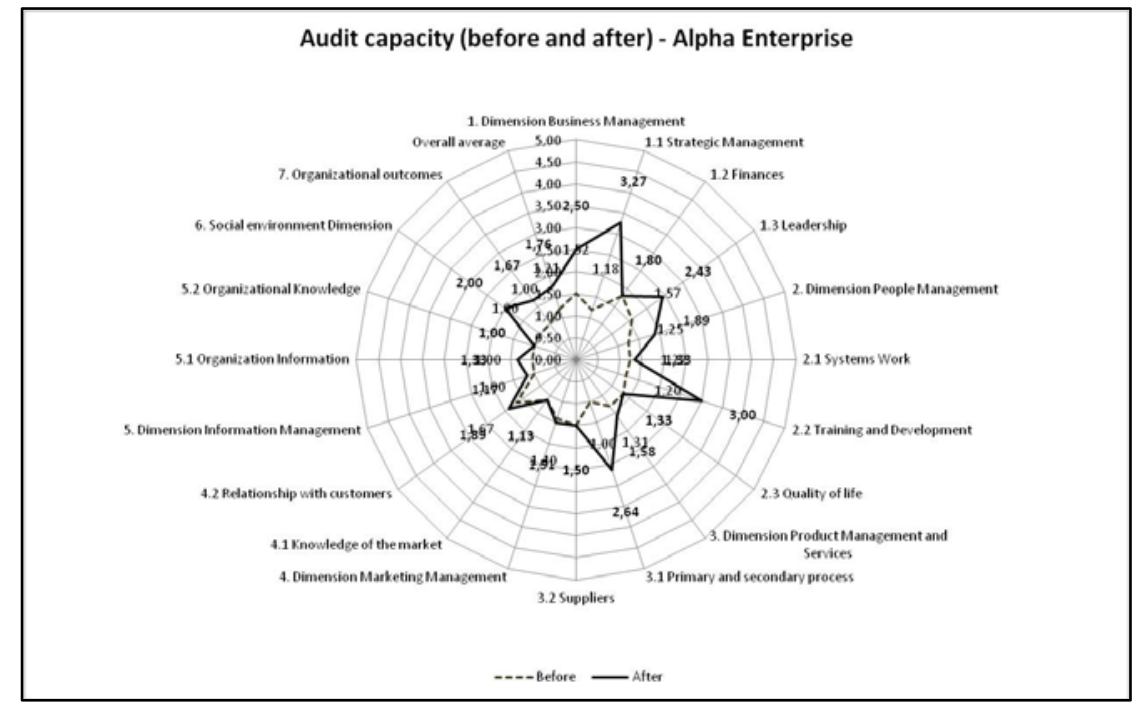

Figure 2: Audit capacity (before and after) - Alpha Enterprise.

The radar contains an analysis of innovation audit (Figure 3) showed significant increases in the final results in relation to the initial stage, mainly in the dimensions innovation input (before 1.50 and after 2.50), especially in training programs and development (before 2.00 and after 4.00 ), the dimension planning of innovation (1.00 before and after 4.00) due to the use of innovative design, dimension and external orientation (before 1.33 and after 2.33). The size of the output innovation we observed an increased (before 1.25 and after 2.25) due to the innovations were concentrated and the organizational processes. In the overall result the company had a score of 1.50 in early intervention through to 2.56 at the end of organizational intervention.

Therefore, the organization demonstrated, as corroborated by radar of audit capacity and innovation audit, a process of transformation through the use of the proposed approach so that through innovations in products and processes the enterprise has become more organized, proactive and innovative. The less significant results observed in radar of audit capability demonstrates the focus of the approach to implementing improvements or innovations in the enterprise, however it needs to be considered by the company as a source for future innovative projects . 


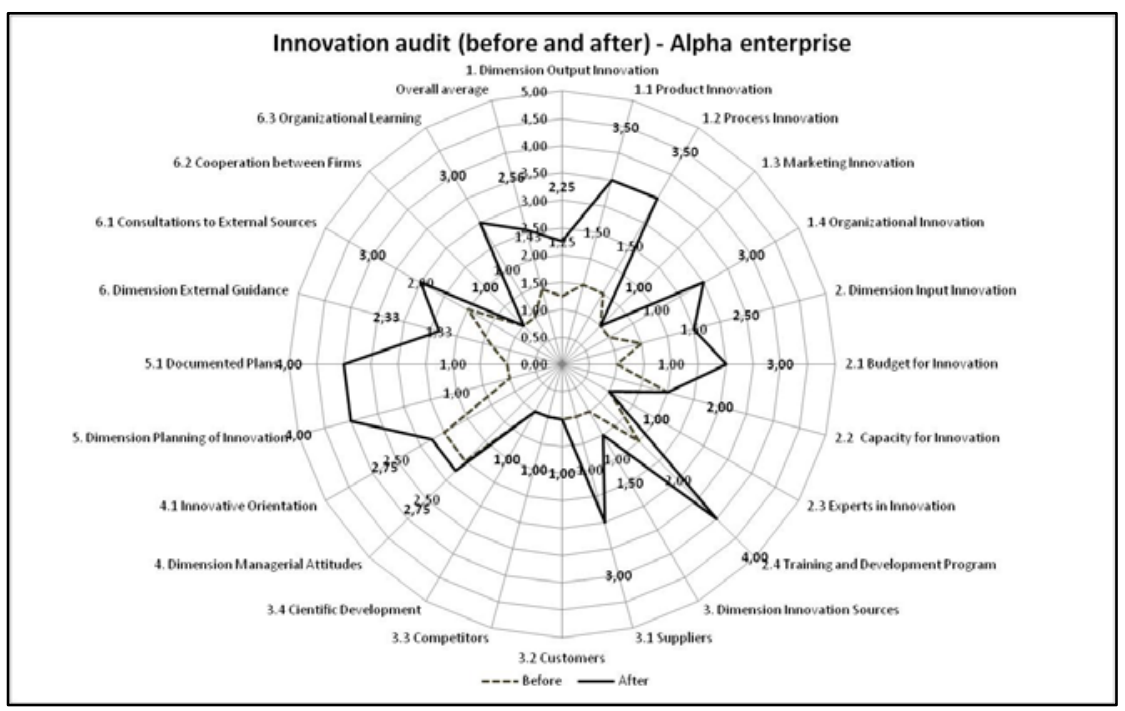

Figure 3: Innovation audit (before and after) of Alpha enterprise.

\section{FINAL CONSIDERATIONS}

The use of innovation management in a small enterprise in the food sector in the city of Manaus allowed identifying, implementing and evaluating the adoption of business practices appropriate management of innovative processes within that enterprise. The main difficulties, needs and opportunities of the enterprise were raised aiming for greater competitiveness in the local market as well as improving the quality of life of workers.

The approach to the innovation management proposed in Coelho (2012) was effective because it was possible to know the internal and external environments and the factors that may influence the type of activity which the enterprise operates. The implementation of these actions was the most complex stage as demanded not only the introduction of new activities, but also the need to deal with the mistrust expected by employees and owners. The stages that comprise the approach (gathering information, diagnosis of the current situation; selection and prioritization; resources; implementation; learning and evaluation) were put into practice and the needs of the enterprise were evidenced by the various tools used. The approach allowed defining what actions would be taken by the enterprise and starting the process of innovation management in the organization.

Can be highlighted as main results: (1) a survey of the major internal and external aspects inherent competitiveness of companies, (2) adoption of an approach and tools for innovation management, (3) developing an action plan and planning for innovation, (4) presentation and discussion with employees and owners of major 
innovations necessary actions aiming and internal improvements, (5) implementation of innovations and improvements in the business, and ( 6 ) acquisition of internal and external knowledge. The entrepreneurial attitude toward innovation is crucial to organizational success as presented in Dyer, Gregersen and Christensen (2009) and corroborates this study.

In summary, the results demonstrate the usefulness of the approach to innovation management in order to increase competitiveness and working conditions in MSEs, but there is the need of the effectiveness of a triple helix model (universityindustry - government) to act and provide these MSEs interactions necessary for the emergence and development of innovations. The relevance of this study lies in applying an approach to innovation management in MSEs that enables such firms a knowledge of their internal and external needs (ambidexterity) and considers the process of innovation as a social nonlinear construct.

\section{REFERENCES}

ABERNATHY, W. J.; UTTERBACK, J. M. (1978) Patterns of industrial innovation, Technology Review, v. 80, n. 7, p. 40-7.

ALTOÉ, L. et al. (2011) As micro e pequenas empresas na exportação brasileira: 1998-2010. Brasília: SEBRAE.

BERKHOUT, G.; HERTMANN, D.; TROTT, P. (2010) Connecting technological capabilities with market needs using a cyclic innovation model, R\&D Management, v. 40 , n. 5 , p. $474-90$.

BESSANT, J. et al. (2005) Managing innovation beyond the steady state, Technovation, v. 25, n. 12, p. 1366-1376.

BÜYÜKÖZKAN, G.; MAIRE J. L. (1998) Benchmarking process formalization and a case study, Benchmarking for Quality Management \& Technology, v. 5, n. 2, p. 101-25.

CARVALHO, H. G. (2009) Gestão da Inovação: inovar para competir: Manual do participante. Brasilia: SEBRAE.

CHESBROUGH, H. W. (2003) The era of open innovation. MIT Sloan Management Review, v. 44, n. 3, p. 35-41.

CHRISTENSEN, C. (1997) The Innovator's dilemma: when new Technologies cause great firms to fail. Boston, Massachussetts: Harvard Business School Press.

COELHO, M. I. B. A. (2012) Gestão da inovação para pequenas empresas: um estudo no setor de alimentos do estado do Amazonas. Rio de Janeiro: UFRJ, 2012. Dissertation (Master in Production Engineering), Instituto Alberto Luiz Coimbra de Pós-Graduação e Pesquisa de Engenharia - COPPE, Universidade Federal do Rio de Janeiro. 
COTEC - FUNDACIÓN COTEC PARA LA INNOVACIÓN TECNOLÓGICA. (1999) Pautas metodológicas de la gestión de la tecnologia y de a innovación para empresas - Temaguide. Tomo I. Introducción, Presentación, CD y Módulo I: "Perspectiva Empresarial". Madrid: Cotec.

DE JONG, J. P. J.; MARSILI, O. (2006) The fruit flies of innovations: a taxonomy of innovative small firms, Research Policy, v. 35, p. 213-229.

DE JONG, J. P. J.; VERMEULEN, P. A. M. (2006) Determinants of product innovation in small firms, International Small Business Journal, v. 24, n. 6, p. 58760.

DOSI, G. (1982) Technological paradigms and technological trajectories: a suggested interpretation of the determinants and directions of technical change, Research Policy, v. 11, p. 147-162.

DRUCKER, P. (1986) Inovação e espírito empreendedor: prática e princípios. São Paulo: Pioneira Thomson Learning.

DYER, J. H.; GREGERSEN, H. B.; CHRISTENSEN, C. M. (2009) The inovator'sDNA. Harvard Business Review, v. 87, n. 12, p. 1-7.

FNQ - FUNDAÇÃO NACIONAL DA QUALIDADE. (2009a) Critérios compromisso com a excelência e Rumo a excelência. São Paulo: Fundação Nacional da Qualidade.

FNQ - FUNDAÇÃO NACIONAL DA QUALIDADE. (2009b) Critérios de excelência/Fundação Nacional da Qualidade. São Paulo: Fundação Nacional da Qualidade.

FREEL, M. S. (2003) Sectoral patterns on small firm innovation, networking and proximity, Research Policy, v. 32, p. 751-770.

FREEL, M. S. (2005) Patterns of innovation and skills in small firms, Technovation, V. 25, p. $123-134$.

GIL, A. C. (2002) Como elaborar projetos de pesquisa. 4. ed. São Paulo: Atlas. GUÉRIN, et al. (2001) Compreender o trabalho para transformá-lo: a prática da ergonomia. São Paulo: Blücher: Fundação Vanzolini.

HANSEN, M. T.; BIRKINSHAW, J. (2007) The innovation value chain, Harvard Business Review, v. 85, n. 6, p. 121-130.

HARVARD BUSINESS ESSENTIALS. (2011) Harvard Business Online/support tools. Available: <http://www.elearning.hbsp.org/businesstools/> Acessed: february 2013.

IBGE - INSTITUTO BRASILEIRO DE GEOGRAFIA ESTATÍSTICA. (2010) Pesquisa de inovação tecnológica: 2008. Rio de Janeiro: IBGE.

KELLEY, T.; LITTMAN, J. (2001) A arte da inovação. 2. ed. São Paulo: Futura.

KLINE, S.; ROSENBERG, N. (1986) An overview of innovation. In: LANDAU, R.; ROSENBERG, N. (Ed.). The positive sum strategy. Harnessing technology for economic growth. Washington D.C.: National Academy Press. 
LONGANEZI, T.; COUTINHO, P.; BOMTEMPO, J. V. M. (2008) Um modelo referencial para a prática da inovação, Journal of Technology Management \& Innovation, v. 3, n. 1, p. 74-83.

MARCONI, M. A. (1990) Técnicas de pesquisa: planejamento, e execução de pesquisas (...). 2.ed. São Paulo: Atlas.

MCNIFF, J. (2011) Action research for professional development: concise advice for new researchers. 2002. Available: http://www.jeanmcniff.com/arbooklet.asp. Acessed: june 2013.

NIETO, M. (2003) From R\&D management to knowledge management. An overview of studies of innovation management, Technological Forecasting \& Social Change, v. 70, p. 135-161.

ROTHWELL, R. (1994) Towards the fifth-generation innovation process, International Marketing Review, v. 11, n. 1, p. 7-31.

SAWHNEY, M.; WOLCOTT, R.; ARRONIZ, I. (2006) The 12 different ways for companies to innovate, MIT Sloan Management Review, v. 47, n. 3, p. 75-81.

SCHUMPETER, J. A. (1961) Capitalismo, socialismo e democracia. Rio de Janeiro: Fundo de cultura.

SEBRAE - SERVIÇO BRASILEIRO DE APOIO ÀS MICRO E PEQUENAS EMPRESAS. (2011) Taxa de sobrevivência das empresas no Brasil. Coleção Estudos e Pesquisas. Brasília: SEBRAE.

SILVA, E. L.; MENEZES, E. M. (2005) Metodologia da pesquisa e elaboração de dissertação. 4. ed. rev. atual. Florianópolis: UFSC.

SILVERSTEIN, D.; SAMUEL, P.; DeCARLO, N. (2009) The innovator's toolkit: 50+ techniques for predictable and sustainable organic growth. New Jersey/USA: Wiley.

SBDC - SMALL BUSINESS DEVELOPMENT CORPORATION. (2011) Bizguides. Australia, SBDC.

THIOLLENT, M. (2007) Metodologia da pesquisa-ação. 15. ed. São Paulo: Cortez. TIDD, J.; BESSANT, J.; PAVITT, K. (2008) Gestão da inovação. 3. ed. Porto Alegre: Bookman.

TRIPP, D. (2005) Pesquisa-ação: uma introdução metodológica, Educação e Pesquisa, v. 31, n. 3, p. 443-466.

VERGARA, S. C. (2009) Métodos de coleta de dados no campo. São Paulo: Atlas. 